\title{
Night temperature and flower abortion of glasshouse cucumber (Cucumis sativus L.)
}

\section{P. J. A. L. de Lint and G. Heij}

Glasshouse Crops Research and Experiment Station, Naaldwijk, Netherlands

Accepted: 14 July 1982

Key-words: cucumber, glasshouse, flowering, fruit production, night temperature, planting date, flower abortion.

\section{Summary}

Four plantings of glasshouse cucumber were grown at three steady night temperatures. Data observed on abortive development of flowers are presented and discussed with respect to fruit production and quality. Abortive development is less serious with later plantings and with lower night temperature. Abortion of second and third flowers is responsible for some $60 \%$ of all abortions, irrespective of treatment. Fruit with a long 'hanging' time are found primilarly in axils just below axils with full abortion. Low fruit quality due to long hanging times thus could be controlled with respect to shelf life to some extend by pruning slowgrowing fruit in these axils.

\section{Introduction}

With the drastic rise in prices of energy it is more than necessary to reduce as much as possible on energy consumption for glasshouse heating. It, therefore, seemed worth-wile to reexamine the relation between production curve, temperature and planting date for glasshouse cucumber cropping even though considerable amounts of data are available (Anon., 1981; Drews, 1979; Hori \& Arai, 1971; Lorenz, 1980; Miller \& Ries, 1958).

Cucumber, in the Netherlands, is grown as a rather high temperature crop with most of the heating used during night hours. Thus an experiment was set up to investigate the effects of lower, and of varying night temperatures on cucumber (van de Vooren et al., 1978). The experiment was carried out in the climate glasshouse of the Glasshouse Crops Research and Experiment Station at Naaldwijk (van de Vooren, 1975, 1977; van de Vooren \& Koppe, 1975).

In the present paper, some data on abortive fruit development out of main stem flowers of the three steady night temperature treatments are reviewed. Data on flowering and on fruiting of the same experimental plants were presented separately (Heij, 1981; Heij \& de Lint, 1982; de Lint \& Heij, 1981, 1982). 


\section{Material and methods}

Cucumber plants, cv. Farbio, an exclusively female flowering variety that develops parthenocarpic fruit (Anon., 1980) were planted out in the climate glasshouse about 30 days after sowing, with fortnightly intervals, viz on 13 and 27 December 1976 and on 10 and 24 January 1977.

Night temperatures used were 12,16 and $20^{\circ} \mathrm{C}$. These different night temperatures were carried on until 1 April 1977. Day temperature was the same for all treatments, viz $21-27^{\circ} \mathrm{C}$ (light-dependent). The switch from night to day was $1 / 2$ hour before sunrise, and from day to night it was at sunset. $\mathrm{CO}_{2}$ concentrations were controlled during day time at $0.1 \%$. From all plants, flower buds and lateral shoot buts were pruned up into the 10 th axil. The main stems were stopped at the level of the suspending wire ( $2.2 \mathrm{~m}$ above border soil level). Lateral shoot buds were removed all the way along the main stem, except for the highest two or three. Nowadays this pruning procedure is common for glasshouse cucumber cropping in the Netherlands (see also Anonymous, 1980; van Uffelen, 1972).

\section{Results 1}

For this experiment the overall percentage of abortive development of flowers was very limited. Out of about 3600 flowers, only 835 aborted shortly after flowering. Differences in the intensity of flower abortion between treatments is shown in Table 1b. Later plantings show less abortion, lower night temperatures result in increased abortion figures. There is not much difference in the number of abortive flowers depending on the position of the plant in the row. Abortion is slightly lower in parallel number 2 (Table 1A).

It is possible to distinguish between two types of abortion with respect to the position of the flowers, viz (a) abortion that results in empty axils with respect to fruit production and (b) abortion in multiflower axils, such that still fruit is produced in that specific axil of the plant.

The data about these types of abortion are presented in Tables 2 and 3, for fruitless axils and for partial abortion respectively. As for the total of abortion, figures for empty axils (Table 2) increase with lower night temperature and they decrease with later plantings. The position of a plant in the row has hardly any effect and the three parallels are highly similar.

Abortion of flowers in multiflower axils is about $60 \%$ of all abortion. Again, figures increase with cooler nights and decrease with later planting. On the row, there is somewhat reduced abortion deeper in to the crop. The position of fully aborted axils along the main stem is presented in Fig. 1. The curve for $12^{\circ} \mathrm{C}$ night temperature clearly shows two peaks, one at axil number 16 and a second one at axils 24 and 25 . For the two higher temperatures the first peak is exactly in the same position. The second peak for these treatments can not be seen, since these plants were decapitated before having enough internodes (Heij, 1981;

1 Original data per plant, from which tables and graphs were derived, are available on request. 
Table 1. Glasshouse cucumber 1977. Number per plant of aborted flowers on the main stem.

A. Parallels 1,2 and 3 , and plant number on the row ( $1 \rightarrow 9$ : into the crop).

B. Night temperature $\left(1=20^{\circ} \mathrm{C}, 2=16^{\circ} \mathrm{C}\right.$ and $\left.3=12^{\circ} \mathrm{C}\right)$, and date of planting $(I=1976-12-13$; II = 1976-12-27; III = 1977-01- 10 and IV = 1977-01-24).

\begin{tabular}{lllllll}
\hline A. Parallel & \multicolumn{2}{l}{ Plant number } & & & \\
\cline { 2 - 5 } & 1 & 3 & 5 & 7 & 9 & mean \\
& & & & & & \\
1 & 5.6 & 6.1 & 4.1 & 5.1 & 3.4 & 4.9 \\
3 & 3.3 & 4.8 & 4.9 & 3.9 & 4.1 & 4.2 \\
Mean & 4.8 & 5.0 & 5.7 & 3.8 & 5.2 & 4.9 \\
\hline B. Planting & 4.5 & 5.3 & 4.9 & 4.3 & 4.2 & 4.7 \\
\cline { 2 - 5 } & 20 & 16 & 12 & mean & & \\
I & 6.6 & 6.7 & 8.7 & 7.3 & & \\
II & 3.7 & 5.1 & 7.3 & 5.4 & & \\
III & 3.0 & 2.4 & 4.4 & 3.3 & & \\
IV & 1.0 & 2.4 & 4.4 & 2.6 & & \\
Mean & 3.6 & 4.2 & 6.2 & 4.6 & & \\
\hline
\end{tabular}

Table 2. Glasshouse cucumber 1977. Number per plant of fully aborted axils on the main stem. A and B: See Table 1.

\begin{tabular}{|c|c|c|c|c|c|c|}
\hline \multirow[t]{2}{*}{ A. Parallel } & \multicolumn{6}{|c|}{ Plant number } \\
\hline & 1 & 3 & 5 & 7 & 9 & mean \\
\hline 1 & 1.8 & 1.8 & 1.7 & 1.9 & 1.8 & 1.8 \\
\hline 2 & 1.4 & 2.2 & 1.8 & 2.0 & 2.2 & 1.9 \\
\hline 3 & 1.6 & 1.9 & 2.7 & $\mathrm{I} .8$ & 2.4 & 2.1 \\
\hline Mean & 1.6 & 2.0 & 2.1 & 1.9 & 2.1 & 1.9 \\
\hline \multirow[t]{2}{*}{ B. Planting } & \multicolumn{4}{|c|}{ Night temperature $\left({ }^{\circ} \mathrm{C}\right)$} & & \\
\hline & 20 & 16 & 12 & mean & & \\
\hline I & 3.2 & 2.3 & 4.9 & 3.5 & & \\
\hline II & 1.6 & 1.5 & 3.5 & 2.2 & & \\
\hline III & 1.3 & 0.7 & 2.5 & 1.5 & & \\
\hline IV & 0.3 & 0.3 & 1.2 & 0.6 & & \\
\hline Mean & 1.6 & 1.2 & 3.0 & 1.9 & & \\
\hline
\end{tabular}

Heij \& de Lint, 1981). However, for the $16^{\circ} \mathrm{C}$ treatment there is some indication of a second rise.

The high proportion contributed to total abortion (Tables 2 and 3 ) by the failure of 'double' flowers invites to analyse the data on 'double' fruits. Fig. 2 (A: 


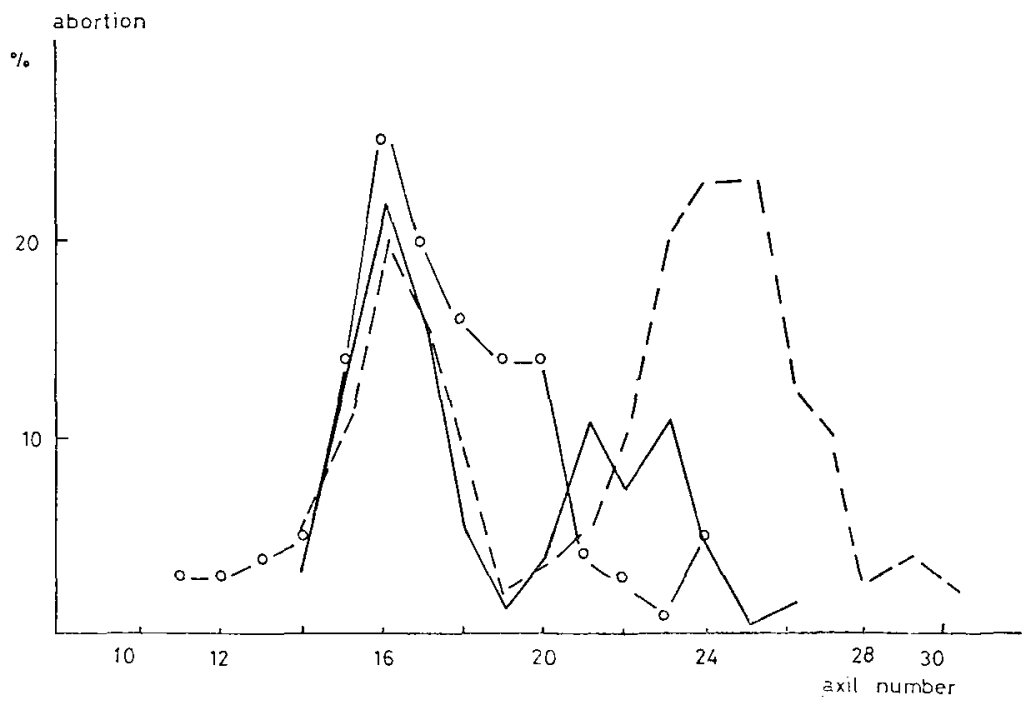

Fig. 1. Glasshouse cucumber 1977. Percentage flower abortion along the main stem under three steady night temperatures $\left(-20^{\circ} \mathrm{C} ; \mathrm{O}-\mathrm{O} 16^{\circ} \mathrm{C} ;--12^{\circ} \mathrm{C}\right.$ ).

night temperature, B: planting date) presents examples of the bearing of average numbers of harvestable fruit per axil, for each treatment. The figures first of all reflect the shapes of the abortion curves of Fig. 1. Furthermore, it is seen that bearing intensity increases towards higher axil numbers. Later planting results in more fruit per axil. The medium night temperature $\left(16^{\circ} \mathrm{C}\right)$ gave higher numbers of fruit per axil than the higher $\left(20^{\circ} \mathrm{C}\right)$ and the lower $\left(12^{\circ} \mathrm{C}\right)$ temperatures (see also Table 4).

Since the cause of an actual abortion of flowers may have consequences on the growth of neighbouring fruit, counts were made on the 'hanging times' of fruit below the fully aborted axils. The results are presented in Fig. 3A and 3B. Fruit in the axil (A-1) immediately under an aborted position (A) has a good chance to grow very slowly. This is less likely for the next lower ones (A-2) and still less for three axils under an aborted one (A-3).

\section{Discussion}

The dependence of abortion on planting date and on night temperature can be evaluated with the data for numbers of stem nodes and total numbers of flowers per stem (Table 5). It will be seen that these three phenomena each are specifically dependent on the two experimental factors applied in such a way that ultimately the number of fruit per stem increases with late plantings and with low night temperature, towards a maximum at $16^{\circ} \mathrm{C}$.

Failure of second and third flowers contributes some $60 \%$ to the total of abor- 
Table 3. Glasshouse cucumber 1977. Number per plant of double abortions (full abortion in multiflower axils) on the main stem.

A and B: See Table 1.

\begin{tabular}{|c|c|c|c|c|c|c|}
\hline \multirow[t]{2}{*}{ A. Parallel } & \multicolumn{6}{|c|}{ Plant number } \\
\hline & 1 & 3 & 5 & 7 & 9 & mean \\
\hline 1 & 4.4 & 5.1 & 3.0 & 3.7 & 1.8 & 3.6 \\
\hline 2 & 2.1 & 3.2 & 3.4 & 2.1 & 2.4 & 2.6 \\
\hline 3 & 3.2 & 3.3 & 3.3 & 2.3 & 3.5 & 3.1 \\
\hline Mean & 3.2 & 3.9 & 3.2 & 2.7 & 2.6 & 3.1 \\
\hline \multirow[t]{2}{*}{ B. Planting } & \multicolumn{5}{|c|}{ Night temperature $\left({ }^{\circ} \mathrm{C}\right)$} & \\
\hline & 20 & 16 & 12 & mean & & \\
\hline I & 3.9 & 4.9 & 4.5 & 4.4 & & \\
\hline II & 2.5 & 4.1 & 4.6 & 3.7 & & \\
\hline III & 1.8 & 1.9 & 2.3 & 2.0 & & \\
\hline IV & 0.8 & 2.3 & 3.7 & 2.3 & & \\
\hline Mean & 2.3 & 3.3 & 3.8 & 3.1 & & \\
\hline
\end{tabular}

Table 4. Glasshouse cucumber 1977. Number per plant of double fruit (second and third fruit per axil) on the main stem.

A and B: See Table 1.

\begin{tabular}{|c|c|c|c|c|c|c|}
\hline \multirow[t]{2}{*}{ A. Parallel } & \multicolumn{6}{|c|}{ Plant number } \\
\hline & 1 & 3 & 5 & 7 & 9 & mean \\
\hline 1 & 7.5 & 4.9 & 3.8 & 3.2 & 3.8 & 4.6 \\
\hline 2 & 2.0 & 3.2 & 2.0 & 2.3 & 2.6 & 2.4 \\
\hline 3 & 3.5 & 3.9 & 3.8 & 3.4 & 2.8 & 3.5 \\
\hline Mean & 4.3 & 4.0 & 3.2 & 3.0 & 3.1 & 3.5 \\
\hline \multirow[t]{2}{*}{ B. Planting } & \multicolumn{4}{|c|}{ Night temperature $\left({ }^{\circ} \mathrm{C}\right)$} & & \\
\hline & 20 & 16 & 12 & mean & & \\
\hline I & 1.5 & 2.4 & 1.1 & 1.7 & & \\
\hline II & 2.3 & 3.9 & 1.8 & 2.7 & & \\
\hline III & 3.2 & 6.3 & 2.9 & 4.1 & & \\
\hline IV & 4.7 & 7.5 & 4.7 & 5.6 & & \\
\hline Mean & 3.0 & 5.0 & 2.6 & 3.5 & & \\
\hline
\end{tabular}

tions, irrespective of treatment. However, the number of fruit from second flowers is still considerable, depending on the treatment. As for the distribution of abortion along the stem, clearly, in and around axil number 16 there is more severe failure of fruit development, and for the lowest night temperature this is 


\section{P. J. A. L. DE LINT AND G. HEIJ}
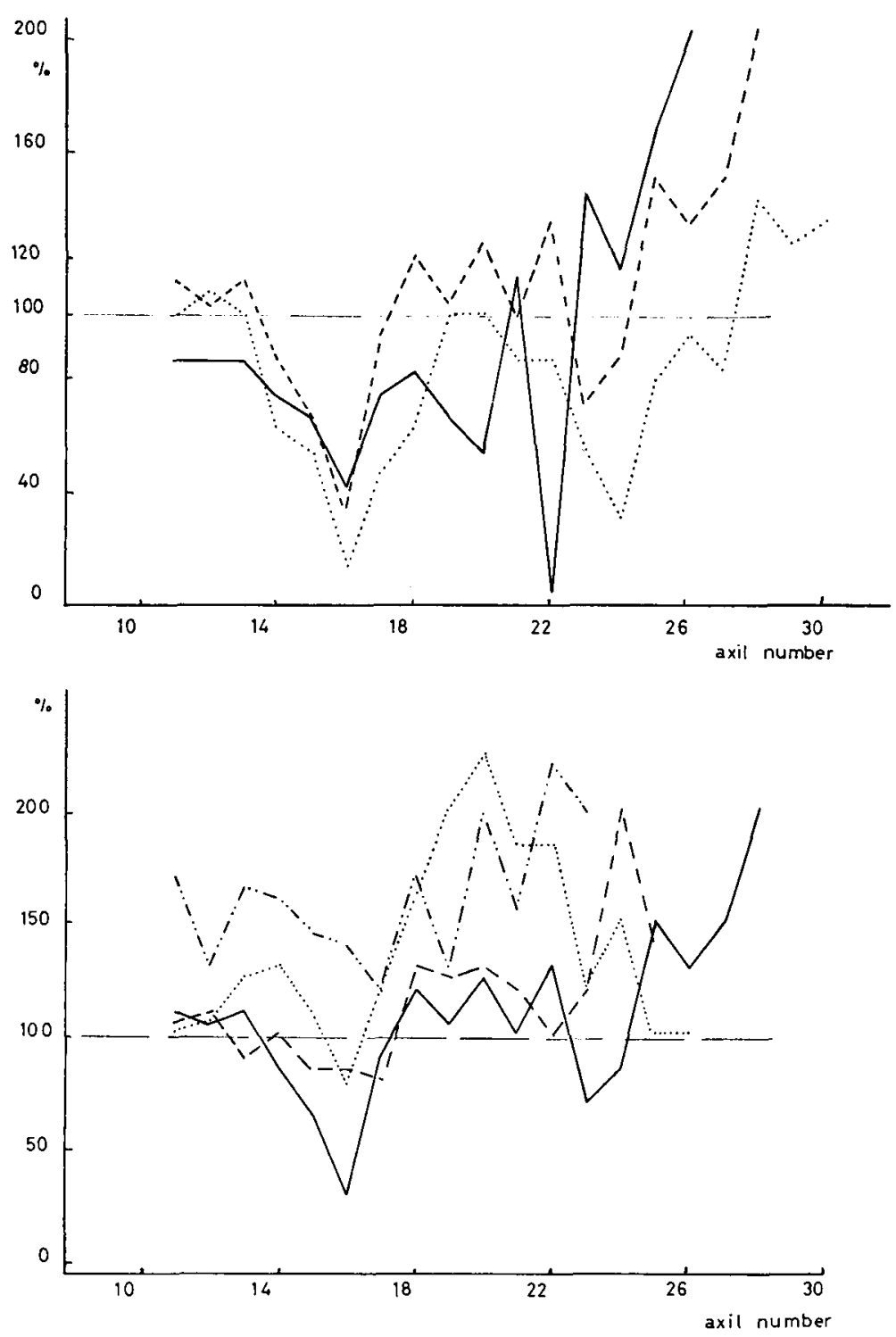

Fig. 2. Glasshouse cucumber 1977. Amount of marketable fruit harvested per axil along the main stem $(100=1$ fruit per axil) versus axil number.

A (top): three steady night temperatures $\left(-20^{\circ} \mathrm{C} ;-\cdots 16^{\circ} \mathrm{C} ; \ldots .12^{\circ} \mathrm{C}\right.$ ).

B (bottom): four planting dates $(-1976-12-13 ;-.--1976-12-27 ; \ldots . .1977-01-10 ;-. .-.-1977-01-$ 24). 

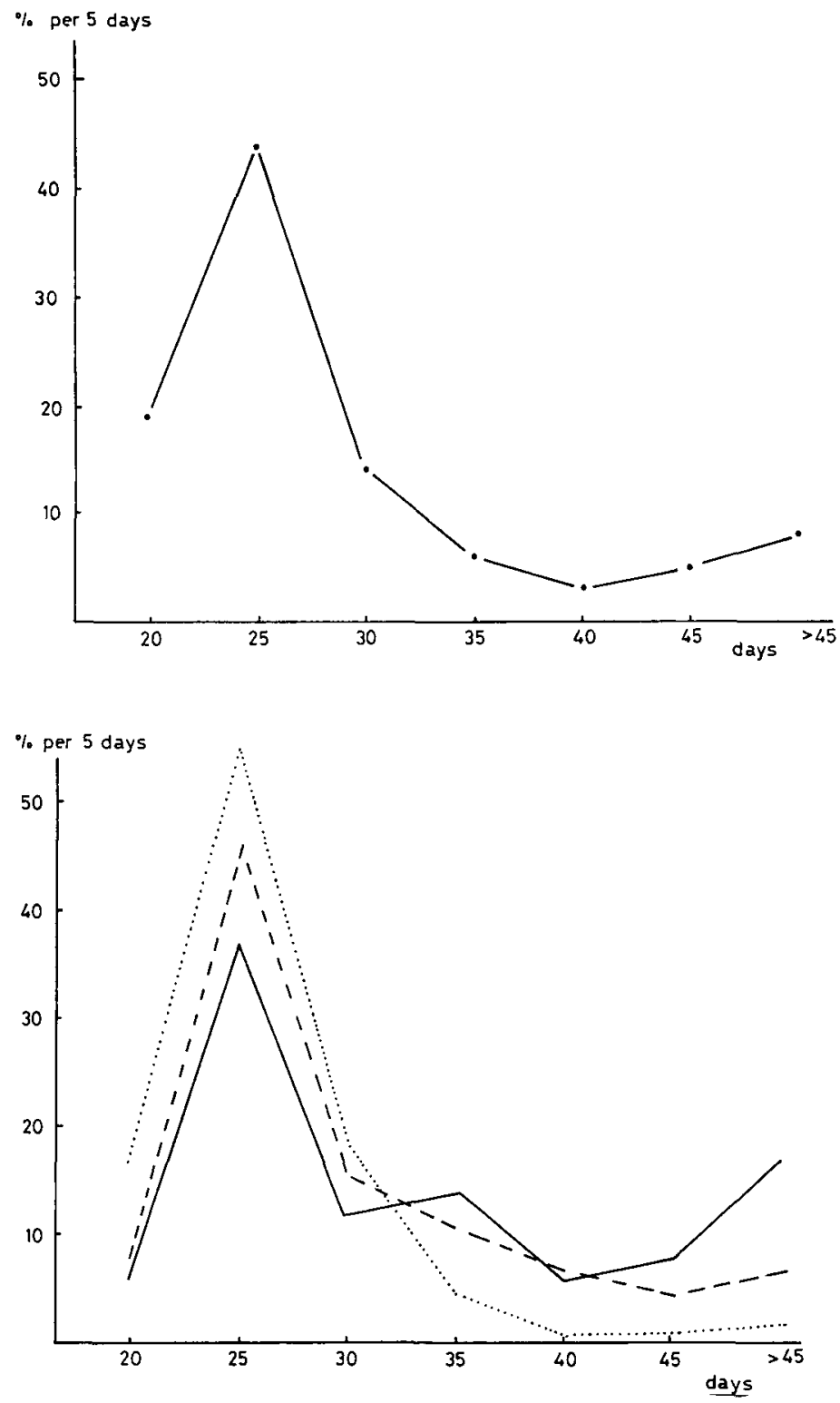

Fig. 3. Glasshouse cucumber 1977. Distribution of hanging time of fruit, per period of harvest of five days, in percentage of the total number of fruit harvested from the main stems (\%) versus hanging time in days.

A (top): distribution for all fruit harvested.

B (bottom): distribution for fruit on axil: (A-1) (--); (A-2) (-..-), and (A-3) (....), A being an axil with spontaneous abortion (see text). 


\section{P. J. A. L. DE LINT AND G. HEIJ}

Table 5. Glasshouse cucumber 1977. Numbers per plant of some main stem composition elements.

A. Data of planting: $\mathrm{I}=1976-12-13 ; \mathrm{II}=1976-12-27$; III $=1977-01-10$ and $\mathrm{IV}=1977-01-24$.

B. Night temperature.

C. Parallels: $1=$ west, $2=$ middle, $3=$ east block position.

D. Plant number: position of a plant in a row of 10 plants (plant 1 being on the outside of the crop).

\begin{tabular}{|c|c|c|c|c|}
\hline Axils & Flowers & Abortions & $\begin{array}{l}\text { Empty } \\
\text { axils }\end{array}$ & $\begin{array}{l}\text { Double } \\
\text { abortion }\end{array}$ \\
\hline
\end{tabular}

$\begin{array}{lrllllll}\text { A. Planting } & & & & & & & \\ \text { I } & 15.3 & 20.1 & 7.3 & 3.5 & 4.4 & 12.8 & 1.7 \\ \text { II } & 15.1 & 20.8 & 5.4 & 2.2 & 3.7 & 15.4 & 2.7 \\ \text { III } & 13.9 & 19.4 & 3.3 & 1.5 & 2.0 & 16.1 & 4.1 \\ \text { IV } & 12.2 & 19.6 & 2.6 & 0.6 & 2.3 & 17.0 & 5.6 \\ \text { Mean } & 14.2 & 20.0 & 4.6 & 1.9 & 3.1 & 15.3 & 3.5\end{array}$

B. Night temperature $\left({ }^{\circ} \mathrm{C}\right)$

$\begin{array}{llllllll}20 & 12.2 & 16.8 & 3.6 & 1.6 & 2.3 & 13.2 & 3.0 \\ 16 & 13.1 & 20.9 & 4.2 & 1.2 & 3.3 & 16.7 & 5.0 \\ 12 & 17.1 & 22.3 & 6.2 & 3.0 & 3.8 & 16.1 & 2.6 \\ \text { Mean } & 14.2 & 20.0 & 4.6 & 1.9 & 3.1 & 15.3 & 3.5\end{array}$

\section{Parallel}

\begin{tabular}{|c|c|c|c|c|c|c|c|}
\hline 1 & 14.6 & 22.0 & 4.9 & 1.8 & 3.6 & 17.1 & 4.6 \\
\hline 2 & 13.7 & 17.9 & 4.2 & 1.9 & 2.6 & 13.7 & 2.4 \\
\hline 3 & 14.1 & 20.1 & 4.9 & 2.1 & 3.1 & 15.2 & 3.5 \\
\hline Mean & 14.2 & 20.0 & 4.6 & 1.9 & 3.1 & 15.3 & 3.5 \\
\hline \multicolumn{8}{|c|}{ D. Plant number } \\
\hline 1 & 14.7 & 21.7 & 4.5 & 1.6 & 3.2 & 17.2 & 4.3 \\
\hline 3 & 14.6 & 21.6 & 5.3 & 2.0 & 3.9 & 16.3 & 4.0 \\
\hline 5 & 14.3 & 19.8 & 4.9 & 2.1 & 3.2 & 15.0 & 3.2 \\
\hline 7 & 13.8 & 18.7 & 4.3 & 1.9 & 2.7 & 14.5 & 3.0 \\
\hline 9 & 13.3 & 18.0 & 4.2 & 2.1 & 2.6 & 13.8 & 3.1 \\
\hline Mean & 14.2 & 20.0 & 4.6 & 1.9 & 3.1 & 15.3 & 3.5 \\
\hline
\end{tabular}

seen again at axil numbers 23 and 24 . This points to some endogenous control mechanism of abortion or to some kind of competition between fruit (Anon., 1981; McCollum, 1934; de Stigter, 1969). However, on the majority of plants there is normal fruit development also in these axils.

In any case, control of fruit load, to optimize production and quality, by means of pruning seems to have only very faint possibilities. Every procedure of systematic pruning of flowers or young fruit in advance of spontaneous abortion must be expected to be either without effect or having a reducing influence on production.

The effect of the position of a fruit relative to aborting flowers on 'hanging' time of fruit (Fig. 3) could be important with respect to fruit quality as shelf life was shown to depend negatively on hanging time (van Esch, 1980; Hilhorst, 1980). Thus, fruit quality may be improved by selective pruning of young fruit that are observed to be slow-growing. But also in this case, production may be reduced to some extend, and it concerns a low percentage of fruit only. 


\section{References}

Anonymous, 1980. Komkommerteelt op steenwol. [Cucumber on rockwool,] 2nd version. Informatieserienummer 43, Glasshouse Crops Research and Experiment Station, Naaldwijk, Netherlands.

Anonymous, 1981. Symposium on Greenhouse Cucumber (edited by G. Heij). Acta Hort. 118.

Drews, Manfred, 1979. Untersuchungen zur Fruchtentwicklung bei der Gewächshausgurke. Arch. Gartenbau, Berlin 27 (H.U.S.) 153-164.

Esch, H. G. A. van, 1980. Komkommers, vaker oogsten geeft betere houdbaarheid. [More frequent harvesting improves shelf life.] Groenten en Fruit 35(37)41-43.

Esch, H. G. A. van, 1980. Nachttemperatuur en houdbaarheid van komkommers. [Night temperature and shelf life in cucumber.] Groenten en Fruit 35(37)48-49.

Heij, G., 1981. Glasshouse cucumber, stem elongation and earliness of fruit production as influenced by temperature and planting date. Acta Hort. 118: 105-121.

Heij, G. \& P. J. A. L. de Lint, 1982. Night temperature and fruiting of glasshouse cucumber (Cucumis sativus L.). Neth. J. agric. Sci. 30: 137-148.

Hilhorst, R. A., 1980. Kwaliteit en houdbaarheid van komkommers. [Quality and shelf life of cucumber.] Groenten en Fruit 35(37)45-47.

Hori, Y. \& K. Arai, 1971. Studies on the effect of day and night temperature on the growth of vegetable crops. I. Growth of young plants of tomato and cucumber affected by day and night temperature and its relation to yield and growth habit of plants after transplanting. Bull. Hort. Res. Stn Hiratsuke Kanagawa Ser. A 10: 206-227.

Lint, P. J. A. L. de \& G. Heij, 1981. Glasshouse cucumber, effects of planting date and night temperature on flowering and fruit development. Acta Hort. 118: 123-134.

Lint, P. J. A. L. de \& G. Heij, 1982. Night temperature and number of nodes and flowering of the main stem of glasshouse cucumber (Cucumis sativus L.) Neth. J. agric. Sci. 30 (1982) 149-159.

Lorenz, H. P., 1980. Modell Untersuchungen zur Klimareaktion von Wachtstumskomponenten am Beispiel junger Salatgurkenpflanzen (Cucumis sativus L.). Ein Beitrag zur Temperaturführung in Gewächshäusern. Dissertation University of Hannover, pp. 138.

McCollum, John P., 1934. Vegetative and reproductive responses associated with fruit development in the cucumber. Mem. Cornell Univ. Agric. Exp. Stn 163.

Miller, C. H. \& S. K. Ries, 1958. The effect of environment on fruit development of pickling cucumbers. Proc. Am. Soc. Hort. Sci. 71: 475-479.

Stigter, H. C. M. de, 1969. Growth relations between individual fruits and between fruits and roots in cucumber. Neth. J. agric. Sci. 17: 209-214.

Uffelen, J. A. M. van, 1972. Plantafstanden en opleidsystemen bij komkommer. [Plant densities and trimming in cucumber.] Groenten en Fruit 27(49)2176.

Vooren, J. van de, 1975. A computer for crop research and climate control in glasshouses. Acta Hort. 51: 169-174.

Vooren, J. van de, 1977. A minicomputer for greenhouse climate control and data analysis. Journal A $18(2)$ 97-98.

Vooren, J. van de \& R. Koppe, 1975. The climate glasshouse at Naaldwijk. Neth. J. agric. Sci. 23: 238-247.

Vooren, J. van de, P. J. A. L. de Lint \& H. Challa, 1978. Influence of varying night temperatures on a cucumber crop. Acta Hort. 87: 249-255. 